\title{
Contesting Syariah Laws in Malaysia: Religion, Human Rights and the State's Response
}

\author{
Marzuki Mohamad ${ }^{1}$ \\ ${ }^{1}$ Associate Professor, Department of Political Science, International Islamic University Malaysia, Malaysia \\ Correspondence: Marzuki Mohamad, Department of Political Science, Kulliyyah of Islamic Revealed \\ Knowledge and Human Sciences, International Islamic University Malaysia, Jalan Gombak, 53100 Kuala \\ Lumpur, Malaysia. E-mail: marzuki_m@iium.edu.my
}

Received: October 9, 2017

doi:10.5539/jpl.v10n5p140

\author{
Accepted: October 20, $2017 \quad$ Online Published: November 29, 2017 \\ URL: https://doi.org/10.5539/jpl.v10n5p140
}

\begin{abstract}
Malaysia is a multiracial country with Islam as the Religion of the Federation. Its Federal Constitution is crafted in a way that Islam - the religion of the Malay majority - occupies special position in the constitution and makes significant presence in public life. But Malaysia is not a full-fledged Islamic state. Secular criminal and civil laws are in force and attempts to introduce Islamic criminal laws ( hudūd) were thwarted by the provisions in the constitution itself. While the more conservative Muslim groups view the entrenched position of Islam in the constitution as one of the most important pillars of Malaysian nation, the more liberal groups see it as a hindrance to the creation of a more liberal and progressive Malaysia. This paper aims at analyzing the contestations between the two groups on the implementation of syariah laws and the impacts of these contestations on politics and law in contemporary Malaysia.
\end{abstract}

Keywords: Malaysia, constitution, human rights, Islam, syariah laws, politics

\section{Introduction}

Malaysia is a Muslim majority country with sizeable multi-racial and multi-religious population. Though Muslims form the majority of Malaysian population, non-Muslims are large in number and wield significant political influence. According to the 2010 population and demographic census, Muslims constituted $61.3 \%$ of Malaysian population followed by Buddhists (19.8\%), Christians (9.2\%) and Hindus (6.3\%). Religion is closely associated with race. A Malay is defined by Article 160 of the Federal Constitution as "someone who professes the religion of Islam, habitually speaks the Malay language and conforms to Malay culture". The Chinese are predominantly Buddhists and the Indians are predominantly Hindus. Christianity, the third largest religion in Malaysia, is professed mostly by the Chinese, Indians and the natives of Sabah and Sarawak.

It is within this context of Muslim-majority plural society that the implementation of syariah laws in Malaysia has generated mixed responses from its civil society. Of late, there have been intense debates on the incompatibility between syariah laws and secular values of human rights and freedoms. The proponents of these values demanded the government to repeal syariah laws that they believe violate basic human rights and freedom. These include the laws that prohibit moral crimes such as close proximity (khalwat), drinking liquor, indecent dressing and renouncing Islam.

However, instead of creating potent forces for an extensive Islamic legal reform along the more liberal lines, the discourse on the incompatibility between syariah laws and western secular conception of human rights and freedom has created strong counter reactions from the more conservative mainstream Muslim groups. They saw it as an attempt to trample on the sanctity of Islam and therefore mobilized popular support to defend the religion. As a result, there have been intense legal and political contestations between the two groups, each trying to influence government policies and court decisions in their favour.

\section{Islamic Law and Human Rights in Malaysia's Plural Society}

In order to better understand the contestations between Islamic law and human rights in Malaysia, a study on this subject should be framed in the context of communal politics and the history of Malaysia's constitution-making in pre-independent Malaya. Due to the competitive nature of communal politics, the process of constitution-making involved hard bargaining between communal leaders who sought to advance communal 
interests, which include matters pertaining to religion. Vorys (1975: 13-14) observed that the single most critical fact that the pre-independence Malayan leaders had come to grips was the dominance of profound communal cleavages among the different ethnic communities and therefore "the terms of intercommunal relations would be promulgated in a constitutional contract then implemented and when necessary augmented by policies secretly negotiated". In Lijphart's model of "consociational democracy", communal leaders engage in "competitive behaviour" that aggravated mutual tension and political instability, but also made "deliberate efforts to counteract the immobilizing and unstabilizing effects of cultural fragmentation" (Lipjhart 1969: 212). In order the avoid the perils of political fragmentation and immobilism, the leaders of different ethnic communities agreed to accept a set of terms which form the basis of Malaysia's constitutional contract, which is sometimes loosely called as Malaysia's social contract.

These terms include special position of the Malays in return for citizenship right for the non-Malays, Malay as the national language and dignified position of Malay rulers which are guaranteed by the Federal Constitution. On religion, the Federal Constitution recognizes Islam as the Religion of the Federation and guarantees the right of every person to freedom of religion. Article 11 of the Federal Constitution provides that "every person has the right to profess and practise his religion", and "no person shall be compelled to pay any tax the proceeds of which are specially allocated in whole or in part for the purposes of a religion other than his own".

It is noteworthy that the right to freedom of religion is granted to every 'person' not just every 'citizen' implying how important religion is to every human being and the Federal Constitution protects that inviolable right. Other than this, Article 11(3) states that every religious group has the right to manage its own religious affairs, establish and maintain institutions for religious or charitable purposes, acquire and own property and hold and administer it in accordance with law.

However, with regard to the propagation of any religious doctrine or belief among persons professing the religion of Islam, Article 11(4) of the Federal Constitution provides that State law and in respect of the Federal Territories of Kuala Lumpur, Labuan and Putrajaya, federal law may control or restrict such propagation. Though this restriction is not in tandem with the liberal conception of human rights and freedom, some scholars view it as necessary in order to preserve public order in a Muslim majority country (Harding 1996: 201; Shad Saleem 2005: 259).

Contrary to the liberal terms of the Lockean-type of social contract, the main aim of which is to promote individual freedom by limiting state powers, the implementation of the main terms of Malaysia's communal-based constitutional contract such as the special position of the Malays and Islam as the religion of the federation, led to the entrenchment of state power rather than limiting it, often at the expense of individual rights and liberties.

Although the terms of the constitutional contract had been agreed upon by the communal leaders at independence, continued internal pressures stemming from each ethnic community for a better deal that will promote their own communal interests have created destabilizing forces in Malaysia's plural society. The continued existence of ethnic fragmentation and its attendant destabilizing forces has provided the state with legitimate justification for the use of extensive state power to maintain political stability and public order. The constitution itself is designed in such a way that it provides the state with vast powers and authority to use various laws and rules that limit individual rights and freedom in favour of maintaining a set of communal interests entrenched in the constitution. The position of Islam and syariah laws is one of these interests.

\section{The Position of Syariah Laws in Malaysia}

The Islamic legal system coexists side by side the secular civil and criminal justice system in Malaysia, creating a dual legal system that has been a subject of much contention. Under this dual legal system, Muslims are subjected to a set of limited Islamic personal and family laws generally known as the syariah laws, the scope of which is defined in the federal constitution. These laws create religious offences ranging from close proximity between unmarried couples to Muslim men's failure to perform Friday prayer. The laws also provide punishments for syariah offences and regulate matters pertaining to Muslim marriage, divorce, custody, maintenance and Islamic charitable organizations. As Islam is a matter that falls within the jurisdiction of the states in Malaysia, except in Federal Territories, the various states establish syariah courts to administer syariah laws.

The legislative power to enact syariah laws are clearly spelt out in the Federal Constitution. List II of the Ninth Schedule of the Federal Constitution, or better known as the State List, read together with Article 74, provides legislative powers of the states in Malaysia to enact syariah laws, which refer to: 
Islamic law and personal and family law of persons professing the religion of Islam, including the Islamic law relating to succession, testate and intestate, betrothal, marriage, divorce, dower, maintenance, adoption, legitimacy, guardianship, gifts, partitions and non-charitable trusts; Wakafs and the definition and regulation of charitable and religious trusts, the appointment of trustees and the incorporation of persons in respect of Islamic religious and charitable endowments, institutions, trusts, charities and charitable institutions operating wholly within the State; Malay customs; Zakat, Fitrah and Baitulmal or similar Islamic religious revenue; mosques or any Islamic public places of worship, creation and punishment of offences by persons professing the religion of Islam against precepts of that religion, except in regard to matters included in the Federal List; ${ }^{1}$ the constitution, Organisation and procedure of Syariah courts, which shall have jurisdiction only over persons professing the religion of Islam and in respect only of any of the matters included in this paragraph, but shall not have jurisdiction in respect of offences except in so far as conferred by federal law, the control of propagating doctrines and beliefs among persons professing the religion of Islam; the determination of matters of Islamic law and doctrine and Malay custom.

In respect of the Federal Territories of Kuala Lumpur, Labuan and Putrajaya, the legislative power to enact syariah laws enumerated under List II of the Ninth Schedule is vested in the Federal Parliament. While the Federal Constitution allows state legislative assemblies, and in the case of federal territories of Kuala Lumpur, Labuan and Putrajaya, the Federal Parliament to legislate on matters concerning syariah laws, the power of legislation only covers matters of personal and family law and a limited number of Islamic criminal offences. It does not extend the power of the state legislatures to enact full-fledged syariah criminal laws on theft, murder, robbery, rape and other criminal offences stipulated in the Penal Code which fall under the purview of the federal Parliament.

The syariah laws of the states and the federal territories are administered by the Syariah courts. In order to ensure the independence of the Syariah courts, article 121 (1A) of the Federal Constitution provides that the High Courts, which exercise the judicial power of the Federation, shall have no jurisdiction in respect of any matter within the jurisdiction of the Syariah courts. Apart from this, Article 145(3) of the Federal Constitution does not extend the power of the Attorney General to institute, conduct or discontinue any proceedings for an offence to the proceedings before a Syariah court. The constitutional guarantee for liberty of persons is also extended to those who are arrested under syariah laws. Similar to an arrest under the federal criminal law, Article 5(4) of the Federal Constitution provides that a person who is arrested for an offence which is triable by a Syariah court, shall without unreasonable delay, and in any case within twenty-four hours (excluding the time of any necessary journey) be produced before a Syariah court judge and shall not be further detained in custody without the Syariah court judge's authority.

The power of the states to punish Muslims for offences under syariah laws was confirmed by the Court of Appeal in Kamariah bt Ali v Kerajaan Kelantan, 3 MLJ 657 (2002). In affirming the limited scope of freedom of religion under Article 11 of the Federal Constitution, the court held:

Article 11 of the Federal Constitution (in relation to Islam) cannot be interpreted so widely as to revoke all legislation requiring a person of the Muslim faith to perform a requirement under Islam or prohibit them from committing an act forbidden by Islam or that prescribes a system of committing an act related to Islam. This was because the standing of Islam in the Federal Constitution was different from that of other religions. First, only Islam, as a religion, is mentioned by name in the Federal Constitution as the Religion of the Federation and secondly, the Constitution itself empowers State Legislative Bodies (for states) to codify Islamic law in matters mentioned in List II, State List, Schedule Nine of the Federal Constitution ('List II')

Similarly, the Federal Court in Lina Joy vs Majlis Agama Islam Wilayah Persekutuan \& Ors, 4 MLJ 585 (2007) re-affirmed the constitutional position of syariah law in Malaysia. In this case, Azlina Jailani, a Muslim woman who attempted to convert to Christianity was told by Malaysia's apex court that she should abide by the regulation or practice stipulated by the syariah law before she can profess Christianity. Tun Ahmad Fairuz, CJ held that:

There was no final decision that the appellant had no longer professed Islam. Thus, the statement that the

\footnotetext{
${ }^{1}$ The Federal List refers to the list legislative powers of the Federal Parliament which include the power to enact laws relating to criminal offences such as murder, theft, robbery and other offences stipulated in the Penal Code, the Dangerous Drugs Act and such other laws that the Parliament may pass.
} 
appellant could no longer be under the jurisdiction of the Syariah Court because the Syariah Court had only jurisdiction on persons professing Islam should not be emphasized accordingly. The way a person renounced from a religion should be in accordance of the regulation or law or practice determined or stipulated by the religion itself ... The freedom of religion under art 11 of the Federal Constitution required that the appellant complied with the rituals or law of the Islamic religion specifically regarding renunciation of the religion. Once the decision of the religion of Islam had been complied and the religious Islamic authority admit (sic) her apostasy then only could the appellant profess Christianity.

\section{Societal Pressures Contesting the Position of Syariah Laws}

Societal pressures contesting the position of syariah laws in Malaysia can be seen as an extension of Malaysian human rights groups' protracted resistance against repressive state laws, which later culminated in a new human rights struggle against the so-called religious-authoritarianism, which refers to a complex constellation of official and un-official Islamic religious laws embedded in state laws and edicts of the ulama' (religious scholars) vigilantly enforced by state religious bureaucrats (Marzuki 2008). Like resistance against repressive laws such as detention without trial under the abolished Internal Security Act (ISA) or limitations to free speech under the Sedition Act, the opposition to the implementation of syariah laws also centred around arguments that these laws violate basic human rights and fundamental liberties understood in its secular-liberal context. The opposition to the implementation and enforcement of syariah laws manifested itself among others in various campaigns against the so-called moral policing by state religious authorities and also attempts to re-interpret provisions of the Federal Constitution pertaining to the validity of syariah laws and the power of Syariah courts by way of court proceedings. It is in a way a direct response from the civil society to the conservative form of Islam sanctioned by the government "in its attempt to prove its Islamic credentials in word and deed" (Lee 2010: 6).

In 2005, a coalition of human rights activists led by Sisters in Islam (SIS) spearheaded a campaign against moral policing by state Islamic enforcement agencies and municipal authorities. They questioned the moral and legal validity of Islamic religious authorities' raids on unmarried couples found in close proximity (khalwat), night club patrons and gamblers which they believed had no basis either in democracy or in Islam. The argument that such actions had no basis in Islam was buttressed by reference to Qur'anic verses such as "Do not spy nor backbite one another" (Surah Al-Hujrat, verse 12) and "Do not enter houses other than your own, until you have asked permission and greeted the occupants" (Surah Al-Nur, verse 27).

Though opposition to the enforcement of syariah laws on matters considered as moral offences, which do not warrant any punishment under secular laws, were based on the more liberal interpretation of Islamic precepts as expounded in the Quran, the real motivation for such opposition was grounded in the groups' belief in secular democratic norms and values. The anti-moral policing campaigners said in a joint statement in response to arrests of night club patrons in Kuala Lumpur that "the balance between law and morality must be decided by society in a democratic manner and not through legislation driven from above with no public support nor public discussion". It also said, "how people dress and where, how and with whom they socialize should be best left to their personal choices", indicating the campaigners' firm belief in secular norms and values in relation to private space and personal freedom.

It was against the backdrop of emerging secular norms and values, especially among the more liberal groups, the opposition to the syariah laws which they viewed as undemocratic, archaic and discriminatory gained traction. In 2004, a group called Article 11 - named after Article 11 of the Federal Constitution which provides for freedom of religion - was formed. The group's primary aim was to uphold the supremacy of the Federal Constitution and to promote religious freedom. It challenged the High Court decision in April 2004 which granted Shamala, a Hindu woman, the custody of her two children but with condition that she must not expose them to Hindu faith because they had been converted to Islam by her estranged husband. The civil court rejected her application to declare the conversion of her two children invalid on the ground that the civil court has no jurisdiction to decide on the correctness or otherwise of the children's conversion as it was a matter for the Syariah court to decide. ${ }^{3}$

In 2013, over 50 non-governmental organizations called Coalition of NGOs in the UPR Process (COMANGO) participated in the Universal Periodic Review (UPR) of the human rights records of all United Nations (UN) member states. ${ }^{4}$ In its report to the UN Human Rights Council for the purpose of 2013 Universal Periodic

\footnotetext{
${ }^{2}$ See joint statement “The State Has No Role in Policing Morality" at http://petitionspot.com/petitions/mamp (Accessed on 7 December 2016)

${ }^{3}$ See Shamala Sathiyaseelan v. Dr Jeyaganesh C Mogarajah \& Anor [2004] 2 CLJ 416.

${ }^{4}$ Members of COMANGO are Pusat Kesedaran Komuniti Selangor (EMPOWER), Suara Rakyat Malaysia (SUARAM), Education and Research Association for Consumers, Malaysia (ERA Consumer), All Petaling Jaya, Selangor Residents' Asscociation (APAC), All Women's Action Society (AWAM), Amnesty International, Malaysia, ASEAN Institute for Early Childhood Development, Association of Women's
} 
Review, COMANGO highlighted "the discrimination faced by women, especially Muslim women during divorce and other matters related to marriage and family; and the escalation of discrimination and violence against lesbians, bisexual women and the transgendered". It also pointed out poor implementation of the Convention on the Elimination of All Forms of Discrimination against Women (CEDAW) Committee's recommendations "especially when they touch on matters which intersect with religion and culture like the requirement of the wali's (guardian) consent for the prospective bride even though she is an adult".

COMANGO also took a swipe at Malaysia's refusal to recognize the rights of lesbians, bisexuals, gays, transgendered, inter-sexed and queer (LBGTIQ) persons citing "a massage centre in Penang was raided 4 times between 2010 and 2011 for offering 'gay massage'; and a fitness centre was raided and the police investigated the case under carnal intercourse against the order of nature; a transgendered person ran away from a centre for 'rehabilitation', effeminate boys were sent to camps to make them more 'masculine', and transgendered persons being attacked by unknown persons". 6

It criticized the state authorities for using Syariah Criminal Offences Enactments "to conduct moral policing, including khalwat (close proximity) raids", which it said "are often subject to abuse by religious enforcement authorities, and such invasions of privacy have, in some instances, resulted in fatal outcomes". It reported that "multiple sections within the Islamic Family Law in Malaysia discriminate against Muslim women, and there have been a roll-back in those rights for example equal rights to marriage, during marriage and its dissolution; right to matrimonial assets; and inadequate protection for a wife upon a husband's entry into a polygamous marriage". COMANGO also slammed the government for promoting Malay supremacy among the Malays who are constitutionally defined as Muslims and claimed that there is no freedom of religion for Muslims of other sects in Malaysia as only the Sunni sect is permitted whereas other sects like Shiite are labelled as 'deviant' and actions may be taken against them.

Having said all these, COMANGO urged the government to repeal section 377A of the Penal Code that criminalises consensual anal and oral sex; prosecute offenders who commit violence, especially those committed against the LBGTIQ; and undertake a comprehensive study on the positive implications and define a clear distinction between the legal system of civil law and syariah laws; repeal or amend the Syariah criminal offences act and enactments that deny the right to privacy, and the provisions that overlap with federal crimes; enact laws, make policies and take administrative steps so that that children are not converted to Islam without the consent of both parents. ${ }^{7}$ More strikingly COMANGO demanded the government to abide by all international human rights instruments that sit uneasily with Islamic law on freedom of religion, Islamic criminal offences and the position of women in Islam.

\section{The Conservative Muslim's Response}

As Malaysia has undergone rapid economic growth since the past four decades, the Malays who previously lived in rural areas, have moved into urban centres and established closer ties with the non-Malays in their neighbourhood and at workplace. As a result of this increased interactions, the ethnic and religious lines are blurring in social, cultural and career life of ordinary Malays. But the diminishing ethno-religious barriers create unintended counter reactions in Malaysian plural society. When religious and ethnic identities are seemingly eroding due to increased cross social and cultural interactions among people of different ethnicities and religions, and also as a result of the proliferation of modern social values and lifestyles, it emboldens internal forces within

Lawyers (AWL), Association of Women with Disabilities Malaysia, Coalition to Abolish Modern Day Slavery in Asia (CAMSA), Centre for Independent Journalism (CIJ), Childline Malaysia, Christian Federation Malaysia, Community Action Network (CAN), Centre for Rights of Indigenous Peoples of Sarawak (CRIPS), Dignity International, Foreign Spouses Support Group, Good Shepherd Welfare Centre, Health Equity Initiatives, Jaringan Kampung Orang Asli Semenanjung Malaysia (JKOASM), Jaringan Rakyat Tertindas (JERIT), Justice For Sisters, Pusat Komunikasi Selangor (KOMAS), Knowledge and Rights with Young people through Safer Spaces (KRYSS), KLSCAH Civil Rights Committee, Land Empowerment Animals People (LEAP), Malaysians Against Death Penalty and Torture (MADPET), Malaysian Child Resource Institute (MCRI), Malaysian Physicians for Social Responsibility, Malaysia Youth \& Student Democratic Movement (DEMA), Migration Working Group (MWG), PANGGAU, Persatuan Masyarakat Selangor dan Kuala Lumpur (PERMAS), PS The Children, PT Foundation, People's Service Organisation (PSO), Seksualiti Merdeka, Perak Women for Women Society, Persatuan Guru-Guru Tadika Semenanjung Malaysia (PGGT), Persatuan Komuniti Prihatin Selangor dan Kuala Lumpur, Persatuan Sahabat Wanita Selangor, Rainbow Genders Society, Sabah Women's Action-Resource Group (SAWO), Southeast Asian Centre for e-Media (SEACem), Sinui Pai Nanek Sengik (SPNS), SIS Forum (Malaysia) Bhd (SIS), Tenaganita, Voice of the Children (VOC), Writers' Alliance for Media Independence (WAMI), Women's Aid Organisation (WAO), Women's Centre for Change, Penang (WCC), Yayasan Chow Kit, Young Buddhist Association, Youth Section, Kuala Lumpur and Selangor Chinese Assembly Hall, Youth Section.

${ }^{5}$ See COMANGO's Stakeholder Report on Malaysia for the 17th Session in the 2nd Cycle of the HRC's Universal Periodic Review in 2013.

${ }^{6}$ See COMANGO's report (above).

${ }^{7}$ See COMANGO's report (above). 
the more conservative religious groups to be culturally and religiously distinctive. The Malay Muslims are experiencing this counter reaction, which Chandra Muzaffar (2002) succinctly described as a process of Islamization.

Islamization is the process by which what are perceived as Islamic laws, values and practices are accorded greater and greater significance in state and society...It is, to some extent, a sincere attempt to restore pure and pristine Islam. It is a quest for the Islamic ideal. At the same time, Islamization is also part of the reassertion of identity - an identity which was, to a lesser or greater degree, suppressed during Western colonial rule. What this means is that Islamization is, in a sense, an endeavour to establish the uniqueness of a civilization which refuses to accept Western domination and control (Chandra: 2002: 219).

In the face of the proliferation of new social values and lifestyles centred around western conception of equality, human rights and freedoms, which sits uneasily with some basic tenets of Islam, the more conservative Muslim mainstream groups organized themselves in defence of Islam. One of these groups is a front called Pertubuhan-Pertubuhan Pembela Islam (Organizations of Defenders of Islam) or its acronym PEMBELA, which comprises main Islamic non-governmental organizations. This Islamic front was formed in 2006 following the controversy over a court application by a Muslim woman, Azlina Jailani, to convert to Christianity. ${ }^{8}$ While the promoters of western conception of human rights and freedoms hailed Azlina's application as a true manifestation of freedom of religion, the conservative Muslims viewed it as a grave sin and heinous crime under the syariah law. PEMBELA represented the voices of the conservative Malaysian Muslims who fear the dilution of Muslim faith and identity as manifested in Azlina's attempt to renounce Islam.

The Muslim conservatives viewed the promotion of western conception of human rights and freedom as an onslaught on the constitutional position of Islam and an attempt to trample on the sanctity of the religion. PEMBELA's press statement released on 31 May 2007 applauding the Federal Court's decision in rejecting Azlina's application to renounce Islam reflected this position:

We welcome and applaud this decision by which we believe that justice has been served. We believe that this decision is a relief for the majority of both Muslims and non-Muslims alike in Malaysia. We say this because we see this decision as vindicating and upholding the existing arrangement relating to the position of Islam and the Syariah courts in the constitutional and legal set-up of the country - an arrangement that has been in place since before independence and 50 years after. It has been well accepted by all communities to the extent that for 50 years after Merdeka (Independence) we have been able to maintain one of the best records in the world for a multiracial multi-religious society to co-exist and build a nation together. In that spirit, this decision should not be perceived as a victory for Muslims and a loss for non-Muslims in Malaysia. Instead it should be seen as a rejection of an attempt by certain individuals and segments (of the society) to deconstruct and radically revamp the current formula. A formula built upon mutual appreciation and understanding of the historical background and social realities of the Malaysian society. One that is in harmony and reflects well with what we are as a nation. ${ }^{9}$

The conservative Muslims' counter-reaction to the proliferation of values associated with the secular conception of human rights and freedom can also be seen in its response to the COMANGO report in 2013. While COMANGO has made vigorous efforts to push for greater freedom with regard to the enforcement of syariah laws by escalating the contentious issue to the international fora, it has also created intense counter reactions from Muslim groups at the domestic level. As most of COMANGO demands were viewed as contrary to the basic teachings of Islam, the group has been labelled as promoting liberalism and a threat to Muslim faith. Ikatan Muslimin Malaysia (ISMA), a Muslim NGO, launched a nationwide campaign against the human rights recommendations made by COMANGO. Called 'Sejuta Ummah Tolak COMANGO' (Community of a million rejecting COMANGO), the campaign included a petition, nationwide rallies and the distribution of leaflets at

\footnotetext{
${ }^{8}$ PEMBELA consists of about 50 member organizations, which include Angkatan Belia Islam Malaysia (ABIM), Wadah Pencverdasan Umat (WADAH), Ikatan Muslimin Malaysia (ISMA), Persatuan, Kebangsaan Pelajar Islam Malaysia (PKPIM), Persatuan Peguam Muslim Malaysia (PPMM), Persatuan Ulama Malaysia (PUM), Kesatuan Pondok Islamiyah Malaysia (ITMAM), Persatuan al-Hunafa (Al-Hunafa), Persatuan Al-Hidayah (Al-Hidayah), Pertubuhan Muafakat Sejahtera Masyarakat Malaysia (MUAFAKAT) and Research and Information Centre on Islam (RICOI).

9 PEMBELA'S

press

statement

http://arkib.harakahdaily.net/arkibharakah/index.php/arkib/berita/lama/2007/5/7926/kenyataan-media-pertubuhan-pertubuhan-pembela-islam -pembela.html (Accessed on 7 October 2017)
} 
mosques after Friday prayers. The leaflets slammed COMANGO for allegedly calling for the freedom to renounce Islam, the protection of LGBT rights, the removal of Malay privileges, the freedom to embrace Shiah teachings, and the right for Catholics to refer to God as "Allah". 10

In response to the formation of COMANGO, a group of Muslim NGOs formed Muslim NGOs in the UPR Process (MuslimUPRo). ${ }^{11}$ The group aimed at monitoring the activities of secular human rights groups in COMANGO that threaten the position of Islam in Malaysia by submitting its recommendations to the United Nations Human Rights Council for the UPR process in Geneva. It accused COMANGO of challenging the position of Islam in Malaysia and spreading "liberalism teachings" backed by Western powers. ${ }^{12}$ In its memorandum to the government, MuslimUPro reminded Malaysian Muslims about the danger of human rights movements which promote secularism, liberalism and pluralism and stressed that Malaysia as an Islamic country must be firm in rejecting their demands which are contrary to the Islamic teachings. It also urged the government to take action against COMANGO for openly rejecting State Syariah Enactments and encouraging Muslims to break syariah laws. ${ }^{13}$

In an effort to counter-balance COMANGO's submission of its memorandum to the UNHRC, MuslimUPRo sent a delegation to participate in the UPR process in Geneva held on 24 October 2013. MuslimUPRO head of delegation, Azril Mohd Amin, said in a statement that the purpose of the group's participation in the UPR process was "to give several suggestions to ensure that human rights issues in general, and those that involve the rights of Muslims in particular, are given fair consideration, and that proposals submitted by Malaysia are properly based on syariah and the Malaysian Federal Constitution". ${ }^{14}$ The group asserted that "issues characterized as syariah-specific and intra-faith be debated academically and in detail among Islamic countries and organisations, with the attendance of syariah experts and scholars of Islamic jurisprudence.....and criticism of syariah laws should not be debated openly by those who are non-Muslims, or those with only secular human rights background, since they negate the role of religion as a comprehensive element in discussing the scope of human rights". MuslimUPRo rejected the interpretation of absolute "universal" values and principles of human rights and that "acceptance of universal values" cannot include the rights of lesbians, gays, bisexuals, and trans-sexuals ("LGBT") which are not recognized by Islam.

The statement further added that as Muslims are the majority and Islam is the religion of the Federation, "issues involving principles of freedom to practice religion must take into account Islamic views, and not be based solely on the absolute freedom to change the religion of any individual Muslim. The statement also maintained that, "as this matter is complex and may cause confusion even among religious people, it is best if interpretations be submitted to Islamic jurists and scholars, and not as revised through the UPR process". To strengthen this argument, the statement made reference to Article 8 of the "Statute of the OIC Independent Permanent Commission on Human Rights" which clearly states that "the Commission shall seek to advance human rights and serve the interests of the Islamic Ummah in this domain, consolidate respect for the Islamic cultures and noble values, and promote inter-civilizational dialogue, consistent with the principles and aims of the OIC Charter." As an active member of the OIC, MuslimUPRo demanded that "Malaysia should seriously support responses in challenge to the UPR on such guidelines as raised in the OIC statute". ${ }^{15}$

As a result of mounting pressures from Muslim groups, the Home Ministry banned COMANGO alleging the majority of groups under its umbrella were un-Islamic and unregistered. The ministry in a statement said COMANGO "was promoting sexual rights contrary to Islam and that only 15 out of its 54 groups were legally registered". It further said, "any group which wishes to run legitimate activities in the country must be registered with the Malaysian Registrar of Societies under the Societies Act 1966 as set in under Section 7 of the Act" and

\footnotetext{
${ }^{10}$ The Malay Mail Online, 8 January 2014.

${ }^{11}$ Muslim UPRo consists of the following organizations: Gabungan Pertubuhan-pertubuhan Pembela Islam (PEMBELA), Persatuan Peguam Muslim Malaysia (PPMM), Pertubuhan Muafakat Sejahtera Masyarakat Malaysia (MUAFAKAT), Ikatan Muslimin Malaysia (ISMA), JATI, Majlis Amal Islami Malaysia, IKATAN, PERKIM, Persatuan Cina Muslim Malaysia (MACMA), PEMBINA, Angkatan Belia Islam Malaysia (ABIM), PERMIM, JATI, PERKID, PERKASA, PROMUSLIM, JAM”IYYAH, Lembaga Kebajikan Perempuan Islam Malaysia (LKPIM), Yayasan Basmi Kemiskinan (YBK), ISSI Malaysia, GABUNGAN Pulau Pinang, PINTA, Majlis Ittihad Ummah, Persatuan Ummah Cemerlang Malaysia, Khalifah Institute, Persatuan Nur Alamiyyah, Pertubuhan Anak Watan Malaysia (WATAN).

${ }^{12}$ The Malay Online, 24 October 2013; Berita Harian, 28 October 2013

${ }^{13}$ MuslimUPRo Memorandum dated 22 October 2013. http://azrilmohdamin.com/2013/10/22/memorandum-muslimupro-22-oktober-2013/ (Accessed on 31 October 2015).

14 MuslimUPRo's Media Statement dated 1st October 2013 http://azrilmohdamin.com/2013/10/01/muslimupros-media-statement-2/ (Accessed on 31 October 2015)

${ }^{15}$ MuslimUPRo Media Statement (above).
} 
declared COMANGO an illegal organization. ${ }^{16}$

\section{Contestations in the Legal Arena}

The social contestations between secular norms and values and the entrenched position of syariah law in the Federal Constitution, which its opponents claimed as undemocratic in nature, were brought into the legal arena in a number of landmark cases involving the issue of freedom of religion. One of these landmark cases was the Lina Joy's case. In 1997, Azlina Jailani, a Muslim woman, applied to the National Registration Department (NRD) to change her name to Lina Lelani. In her statutory declaration in support of the application, she stated that she intends to marry a Christian man. Under Malaysian syariah law, a Muslim is prohibited from marrying a non-Muslim. ${ }^{17}$ The application was rejected by NRD and she applied again to change her name and to remove the word "Islam" from her identity card. Again, the NRD rejected her application. She then challenged NRD's decision in court, arguing that "she has a freedom to profess a religion of her choice under Article 11(1) of the Federal Constitution, which supersedes any other Federal or State laws and that her freedom to profess is a matter of personal choice and not to be dictated by any party". ${ }^{18}$

To her disappointment, the High Court rejected her application on the ground that freedom of religion under Article 11 of the Federal Constitution is not an absolute right, but subject to constitutional provision relating to the right of religious authority to manage its own affairs. Justice Faiza Thamby Chik in his judgment said:

Article 11(1) of the Federal Constitution provides that every person has the right to profess and practise his religion, this does not mean that the plaintiff can hide behind this provision without first settling the issue of renunciation of her religion (Islam) with the religious authority which has the right to manage its own religious affairs under art. 11(3)(a) of the Federal Constitution. If the plaintiff is allowed to do so, this will create chaos and confusion with the administrative authority which manages the affairs of Islam and the Muslim community and consequently the non-Muslim community as a whole. I am of the opinion that this would threaten public order and this cannot have been the intention of the Legislature when drafting the Federal Constitution and the Act. ${ }^{19}$

Azlina appealed to the Court of Appeal and then the Federal Court. But on both occasions her appeal was rejected. Emphasizing that the act of renouncing Islam is subject to Islamic laws, the Federal Court held:

Islam is not only a collection of dogma and rituals but it is also a complete way of life comprising of all kinds of human, individual or public, legal, political, economic, social, cultural or judicial activities. And when reading arts 11(1), 74(2) and item 1 in second list of the Ninth Schedule of the Federal Constitution it was obvious that Islam among others included of (sic) Islamic law. Hence, if a Muslim intends to renounce from Islam, he is actually exercising his rights in the syariah law context which has its own jurisprudence relating to apostasy. ${ }^{20}$

In 2012, there was another case that challenged the constitutionality of the syariah law. Four transgender individuals filed an application at the Seremban High Court to challenge the ban on Muslim men to dress and pose as women under Section 66 of the Syariah Criminal (Negeri Sembilan) Enactment. They applied for a judicial review to declare Section 66 of the enactment unconstitutional.

The four applicants, Muhamad Juzaili Mohd Khamis, Shukor Jani, Wan Fairol Wan Ismail, and Adam Shazrul Mohd Yusoff who worked as bridal make-up artists identified themselves as women and dressed as women. All four had been arrested under section 66 of the Syariah Criminal (Negeri Sembilan) Enactment for several times since 2005 and fined by the Syariah court. They claimed that as a result of the enactment, they had difficulty to move about and this violated their rights under Article 9 (2) regarding mobility. They also claimed that, among others, Section 66 violates Article 5 on liberty, particularly their freedom of choice and denies them the right to freely express themselves.

The High Court on 11 October 2012 dismissed their application but granted them leave to challenge the enactment in the Court of Appeal. In a landmark decision, the Court of Appeal on 22 May 2014 allowed their appeal. Delivering the judgment, Justice Hishamuddin Mohd Yunus held that "section 66 of the Enactment is

\footnotetext{
${ }^{16}$ The Malay Mail Online, 8 January 2014.

${ }^{17}$ Under Malaysian syariah law, both Muslim men and women are prohibited from marrying a non-Muslim. See for example Section 10, Islamic Family Law Enactment (Selangor) 2003.

${ }^{18}$ Lina Joy v. Majlis Agama Islam Wilayah Persekutuan \& Anor [2004] 6 CLJ 242.

${ }^{19}$ Lina Joy v. Majlis Agama Islam Wilayah Persekutuan \& Anor [2004] 6 CLJ 242.

${ }^{20}$ [2007] 4 MLJ 585.
} 
inconsistent with Article 5(1) of the Constitution as it deprives the appellants of their right to live with dignity. Section 66 is irreconcilable with the existence of the appellants and all other Gender Identity Disorder (GID) sufferers". The court further held that "the State and section 66 of the Enactment simply ignored GID sufferers such as the appellants and unfairly subject them to the enforcement of law". It also said that the section "is discriminatory on the ground of gender and therefore, violates Article 8(2) of the Constitution as it subjects male Muslim persons like the appellants to an unfavourable bias vis-a-vis female Muslim persons". In agreement with the appellants' contention, the court found that the section "is explicit in criminalising any Muslim man who wears a woman's attire or poses as a woman in any public place.... and denies the appellants and sufferers of GID the right to move freely in public places... without being exposed to being arrested and punished". A person's dress, attire or articles of clothing, the judge said, "are a form of expression which is guaranteed under Article 10(1)(a) of the Constitution. Based on these findings, the court finally held that section 66 of the Enactment is invalid as being unconstitutional. ${ }^{21}$

Gender rights activists immediately applauded the Court of Appeal's judgement. Celebrating the victorious day, Nisha Ayub of Justice for Sisters (JFS) said, "today is not just a crucial day for Muslim transgendered women, but it is a crucial day for all Malaysians ... today will also reflect the Malaysian stand on human rights and equality for all."22 But the jubilant mood was short-lived. The State of Negeri Sembilan along with five other appellants including the Islamic Religious Affairs Department of Negeri Sembilan filed an appeal in the Federal Court. On 8 October 2015, the Federal Court overturned the Court of Appeal's decision.

Delivering the Federal Court's judgment, Justice Tan Sri Md Rauf Sharif, said that "judges of the Court of Appeal as well as the High Court were in grave error in entertaining the respondents' application to question the validity or constitutionality of section 66 by way of judicial review". Under Clauses (3) and (4) of Article 4 of the Federal Constitution, such application shall not be commenced without the leave of a judge of the Federal Court. Citing substantive procedural non-compliance, the judge held that "the courts below were not seized with jurisdiction to do so, and the proceedings heard by them were null and void ab initio". In his judgment, the judge said:

The issue here was not whether the appellants were prejudiced by the mode of action undertaken by the respondents. The case raised a larger issue. It was about the jurisdiction of the courts. The fundamental question was whether the validity or constitutionality of section 66 could be challenged in the High Court by way of a collateral attack in a judicial review proceeding ... the application for declarations sought by the respondents before the High Court by way of judicial review was in fact a challenge to the legislative powers of the State Legislature of Negeri Sembilan. What the respondents wanted to do was to limit the legislative powers of the State Legislature, by saying that despite the powers to legislate on matters on Islamic law having been given to the State Legislature by Article 74 of the Federal Constitution read with List II in the Ninth Schedule thereof, that legislation must still comply with the provisions on fundamental liberties in Articles 5(1), 8(2), 9(2) and 10(1) of the Federal Constitution. The application for the declarations sought by the respondents was incompetent by reason of substantive procedural non-compliance with Clause (3) and (4) of Article 4 of the Federal Constitution, and should have been dismissed by the High Court on the ground that the High Court had no jurisdiction to hear the matter.

The apex court's decisions in Azlina's case and the Negeri Sembilan transgenders' case show that the position of syariah laws are strongly entrenched in the Federal Constitution. So far, it has been the attitude of the apex court to affirm the position of syariah laws in the constitution and stave off any attempt to circumvent its enforcement.

\section{The State's Response}

Being a multi-racial and multi-religious country, Malaysia has chosen the path of moderation not extremism in managing ethnic and religious relations. Not only moderation (wasatiyyah) forms the core teaching of the Sunni school of thought to which the majority of Malays belong, it is also politically expedient to do so in a plural society. The Malaysian semi-democratic set up which allows political parties representing different ethnic communities to contest in relatively competitive elections has made political or religious extremism unpopular and uncalled for. As Muhammad Kamal Hassan (2011: 2-3) observes:

Politically the system allows for secular-based opposition parties as well as a strong Islamically-based opposition party which has defeated government parties in several elections and is still in control of two states in Malaysia. The winning formula for all communities has

\footnotetext{
${ }^{21}$ Muhamad Juzaili Mohd Khamis \& Ors v. State Government of Negeri Sembilan \& Ors [2015] 1 CLJ 954

${ }^{22}$ The Malay Mail Online, 22 May 2014.
} 
always been one in which there is a realistic recognition of the pluralistic nature of the nation and the need to balance between the particular interest of a community and the larger interest of national stability, national security and national wellbeing, without stepping beyond the limits of freedom provided for in the Constitution of the nation. Therefore, the voice of moderation is the preferred voice even within the Muslim community...

Although Islam is the religion of the federation and it occupies a special position in the Federal Constitution, Malaysia is not an ideal-type Islamic state that adopts full-fledge syariah laws as the basis of its judicial and legal system. This is in tandem with the common trend in most countries in the Muslim world that adopt modern written constitution (Zoya 2007: 17). Being a Muslim-majority country which is pluralistic in nature, Malaysia had attempted to chart a course of Islam as a progressive religion relevant to the modern world (Abdul Rahman 2007: 129).

However, the progressiveness of state-defined Malaysia's Islam moves like a pendulum swing. More often than not, it was determined by the contest for Malay votes among the Malay-based political parties. In the 1970s through the mid-1990s, the contest for Malay votes between the ruling United Malays National Organization (UMNO) and the opposition Pan-Malaysian Islamic Party (PAS) resulted in the "Islamization race" or "Islamicity race" which saw both parties attempting to outbid each other on Islam with each trying to prove that it is more Islamic than the other (Barton 2002, Farish 2004). While PAS tried to show that the party represented a more authentic version of Islam, UMNO too attempted to impress upon the Malays that the party stood for the real Islam both in form and substance. The result of this "Islamization race" in the electoral contest for Malay votes was the intensification of the implementation of Islamic policies and programs by the government.

However, beginning from the mid-1990s onwards, the push for liberalization in the economy and society has changed the Islamic discourse in Malaysia. A more modern and progressive outlook of Islam has been promoted by UMNO through the discourse of Melayu Baru (the New Malay), Masyarakat Madani (Civil Society) and later Islam Hadhari (Civilizational Islam). PAS too promoted a new version of Islam after it formed alliance with the secular and predominantly Chinese Democratic Action Party (DAP) in the 1999 general election. Through the concept of Negara Berkebajikan (Welfare State) and its PAS for All slogan, the once conservative Islamic party steered its direction toward one which is more compatible with democracy and human rights in an attempt to win the support of non-Malays and urban Malays, and expand its support base beyond its traditional core followers among conservative Muslims in rural areas. For once, the Islamization race seems to have lost its steam.

However, this does not mean that the contest for Malay votes has ended and the use of Islam as bait for votes has completely been abandoned by the Malay-based political parties. Until recently, the Malays still form the backbone of BN's vote bank. In the $13^{\text {th }}$ general election held in 2013, BN barely won the election with an average $52 \%$ of Malay votes and $25 \%$ of Chinese votes. With recent poll showed the Chinese support for BN dropped to about $14 \%,{ }^{23} \mathrm{BN}$ 's victory in the next general election will mainly depend on the strength of Malay support for the party.

At the same time, due to the pressing economic issues like the implementation of Goods and Services Tax (GST), rising prices, fuel price hike and rising cost of living, which hit ordinary Malaysians the hardest, BN's approval rating among the electorates is as low as $36 \%{ }^{24}$ Due to the $1 \mathrm{MDB}$ scandal which allegedly involved the Prime Minister Najib Razak himself and allegations of corruption in relation to the RM2.6 billion 'donation' in his personal bank account, the Prime Minister's approval rating has dropped to as low as $18 \%{ }^{25}$

It is in the midst of BN's declining popularity among the electorates that race and religion came into play again as bait for votes. Reacting to the massive two-day Bersih rally in Kuala Lumpur on 29 and 30 August 2015, UMNO leaders accused the yellow-shirt Bersih rally, which was attended mostly by the Chinese, as an attempt by the pro-opposition Chinese to trample on the Malay rights. The photo of a young Chinese woman stomped on the portraits of the Prime Minister and PAS President Abdul Hadi Awang, was viral on the social media. The rally, the primary aim of which was to demand for clean and fair election, has turned into a show of public displeasure toward the Prime Minister.

In response to the so-called 'Chinese threat' against 'Malay dignity', UMNO, in defiance of concerns raised by non-Malay leaders of BN component parties, mobilized thousands of its core supporters clad in red t-shirts to gather in Kuala Lumpur on 16 September 2015 to show support for the embattled Prime Minister. In a haste to

\footnotetext{
${ }^{23}$ Opinion poll conducted by Merdeka Centre for Opinion Research in August 2017.

${ }^{24}$ What Malaysians Want survey conducted by International Islamic University Malaysia researchers in July 2017.

${ }^{25}$ What Malaysians Want Survey (above).
} 
play the race card to consolidate Malay support for the Prime Minister, the Malaysia Day red shirt rally has turned into a show of Malay force to scare the non-Malays especially the Chinese. A group of demonstrators were seen rioting in Petaling Street, a popular spot for Chinese traders, apparently in an attempt to vilify the Chinese.

Playing the race card for support, Najib in an event organized by a silat (Malay martial art) association two days after the red-shirt rally, ignored his own 1Malaysia campaign which calls on all Malaysians regardless of race and religion to accept each other as Malaysian, by openly praising the red-shirt demonstrators for their bravery to stand up in defence of Malay leader. ${ }^{26}$ This turn of events was quite understandable given UMNO's main pre-occupation was to consolidate its Malay support.

With BN being overly dependent on the Malay votes to win the next general election, it is very unlikely that the government will entertain any attempt to challenge the position of Islam and the syariah laws, which was considered too sensitive by the conservative Malays. UMNO was even willing to go the extra mile by allowing its state legislators to support Amendments to Kelantan's Syariah Criminal Code 1993 (the Hudud Bill). With the unprecedented support from all Kelantan UMNO state assemblymen, the PAS-led Kelantan State Legislative Assembly unanimously passed the Hudud Bill on 19 March 2015.

Following the passage of the Hudud Bill in the Kelantan State Assembly, PAS President Abdul Hadi Awang in his capacity as a Member of Parliament submitted a Private Member's Bill to the House of Representative in April 2015 to amend the Syariah Courts (Criminal Jurisdiction) Act 1965. The proposed amendments to Section 2 of the Act is to increase the current "imprisonment of more than three years or fine of more than RM5,000, or more than six lashes" to "jail term of more than 30 years or fine more than RM100,000 or 100 lashes as administered in line with the syariah crimes". ${ }^{27}$

Currently, in exercising its criminal jurisdiction under section 2 of the existing Act, the Syariah court may punish an offender with imprisonment for a term not exceeding three years, or fine not exceeding five thousand ringgit or whipping not exceeding six strokes or any combination thereof. This section limits the power of the syariah court to mete out punishment for certain hudud offences like zina (adultery) involving unmarried persons which is 100 lashes. The proposed amendments to Act, if passed by the Parliament, will enable the syariah court to mete out punishments for some of the hudud offences.

The private member's Bill submitted by Hadi was rejected by the leaders of BN component parties. Members of Parliament from BN component parties in Sabah and Sarawak said they will not vote for the Bill if it is tabled in the Parliament. Wilfred Madius Tangau, the President of United Pasokmomogun Kadazandusun Murut Organisation (Upko), a Sabah-based BN component party, led Sabah and Sarawak BN leaders in opposing the private member's Bill. ${ }^{28}$ Gerakan, a predominantly Chinese BN component party, filed a lawsuit in Kota Bharu High Court on 18 March 2015 in a bid to stop the Kelantan state government from introducing hudud laws in the state.

By end of 2016, the private member's Bill submitted by Hadi has yet to be debated in the Parliament. However, some UMNO politicians have expressed their support for the Bill. They include Deputy Prime Minister and UMNO Vice-President, Ahmad Zahid Hamidi, who maintained that the Bill proposed by Hadi is necessary in order to uplift the status and position of Islamic legal system in Malaysia. ${ }^{29}$ Muslim NGOs also joined the fray in expressing their support for the Bill. About 500 Islamic non-governmental organizations formed a coalition called Sekretariat Ummah urging Muslim members of parliament to support the Bill. ${ }^{30}$ On 18 February 2017, PAS organized a mammoth rally of about 20,000 supporters in Kuala Lumpur to garner public support for the proposed amendment. The rally was also attended by Minister in the Prime Minister's Department in charge of Islamic affairs and UMNO Supreme Council member, Jamil Khir Baharom, who spoke at the event emphasizing the necessity of the amendment in an effort to uplift the status of syariah courts in Malaysia. ${ }^{31}$

This stance by UMNO politicians is not something unexpected. They know the importance of endearing themselves to the Islamic groups and capitalize on the Islamic narratives to win the Malay votes. It seems that the "Islamization race" has not lost its steam. It moves like a pendulum swing. When the time is right, it will re-appear in the political discourse and practice to serve its purpose of winning the Malay votes. As Chandra Muzaffar (2002:

\footnotetext{
${ }^{26}$ Straits Times, 20 September 2015.

${ }^{27}$ New Straits Times, 6 April 2017.

${ }^{28}$ Free Malaysia Today, 23 March 2015.

${ }^{29}$ Utusan Malaysia, 23 November 2016.

${ }^{30}$ Astro Awani, 24 November 2016.

${ }^{31}$ Berita Harian Online, 18 February 2017.
} 
220) puts it, "the state itself uses (Islamization) to cut the ground from under the feet of its opponents. Through Islamization, it tries to increase its popularity, enhance its legitimacy. Islamization is even manipulated to sanction the control of society".

With the present political scenario, it is very unlikely that the proponents of the secular-liberal conception of human rights and freedom will be successful in their bid to challenge the position of syariah laws in Malaysia. It will be a daunting task for them to influence the government to repeal or amend the syariah laws that they believe violate basic human rights and freedoms. However, as the ruling government is also facing declining support from the non-Malays, it will be equally fatal for the government to introduce new syariah laws and policies that will further alienate the non-Malays, especially the non-Muslim Bumiputeras in Sabah and Sarawak, who were hitherto regarded as BN's loyal supporters. So far, the most likely outcome of these contestations is the maintenance of the status-quo.

\section{Conclusion}

Societal pressures contesting the position of syariah laws in Malaysia is a result of changing social values in society as well as a reaction to the government's affirmation of the more conservative outlook of Islam in the public sphere. However, these pressures which mainly revolved around civil society activism to challenge the validity of syariah laws in a predominantly conservative Muslim society have generated counter reactions from the conservative Muslims. They have organized themselves to oppose any efforts to challenge the position of Islam and syariah laws and deemed such attempt as a threat to the Muslim faith and the dignity of Islam. So far, the counter reactions from the conservative Muslims have provided justifications for the government to avoid reforming the Islamic legal and judicial system along the more liberal lines. The ruling party instead intensified its stance on Islam on the ground of uplifting the status and position of syariah court in its bid to win the Malay votes. Faced with its declining popularity and high dependence on the conservative Malay votes to win elections, it is very unlikely that the $\mathrm{BN}$ government will heed to the pressures for the repeal of certain syariah laws that will make itself unpopular among the Malay-Muslim electorates.

\section{References}

Embong, A. R. (2007). Islam and democracy in Malaysia. In Z. Hassan (Ed.), Democracy in Muslim Societies. Los Angeles: Sage Publications. https://doi.org/10.4135/9788178299679.n5

Faruqi, S. S. (2005). The Malaysian constitution, the Islamic state, and hudud laws. In K. S. Nathan, \& M. H. Kamali (Eds.), Islam in Southeast Asia: Political, Social and Strategic Challenges for the $21^{\text {st }}$ Century. Singapore: ISEAS.

Greg, B. (2002). Islam, Society, Politics and Change in Malaysia. In I. Jason, \& Rubenstein (Eds.), Islam in Asia. London: Transaction Publishers.

Harding, A. (1996). Law, Government and the Constitution in Malaysia. Kuala Lumpur: Malayan Law Journal.

Hassan, M. K. (2011). Voice of Islamic Moderation from the Malay World. Kuala Lumpur: EMIR.

Hassan, Z. (2007). Democracy in Muslim Societies. Los Angeles: Sage Publications. https://doi.org/10.4135/9788178299679

Lee, Julian C. H. (2010). Islamization and Activism in Malaysia. Singapore: ISEAS.

Lijphart, A. (1969). Consociational Democracy. World Politics, 21(2), 207-225. https://doi.org/10.2307/2009820

Mohamad, M. (2008). Religion, human rights and constitutional-contract politics in Malaysia. Intellectual Discourse, 16(2), 155-186.

Muzaffar, C. (2002). Rights, Religion and Reform: Enhancing Human Dignity through Spiritual and Moral Transformation. London: RoutledgeCurzon.

Noor, F. (2004). Islam Embedded: The Historical Development of the Pan-Malaysian Islamic Party PAS (1951-2003). Kuala Lumpur: Malaysian Sociological Research Institute.

Vorys, K. (1975). Democracy Without Consensus: Communalism and Political Stability in Malaysia. Princeton, New Jersey: Princeton University Press.

\section{Copyrights}

Copyright for this article is retained by the author(s), with first publication rights granted to the journal.

This is an open-access article distributed under the terms and conditions of the Creative Commons Attribution license (http://creativecommons.org/licenses/by/4.0/). 